\title{
sciendo
}

\section{EVALUATION OF SLAUGHTER PARAMETERS AND MEAT QUALITY OF RABBITS FED DIETS WITH SILKWORM PUPAE AND MEALWORM LARVAE MEALS*}

\author{
Dorota Kowalska ${ }^{\star *}$, Andrzej Gugołek ${ }^{2}$, Janusz Strychalski² \\ ${ }^{1}$ Department of Small Livestock Breeding, National Research Institute of Animal Production, \\ 32-083 Balice n. Kraków, Poland \\ ${ }^{2}$ Department of Fur-bearing Animal Breeding and Game Management, \\ Faculty of Animal Bioengineering, University of Warmia and Mazury, Olsztyn, Poland \\ •Corresponding author: dorota.kowalska@izoo.krakow.pl
}

\begin{abstract}
The aim of this study was to determine the effect of feeding rabbits with diets containing dried silkworm pupae and mealworm larvae meals on their slaughter value and meat quality. A total of 60 New Zealand White rabbits at 35 days of age were divided into 3 equivalent groups. Control group (C) and two experimental diets included either $4 \%$ silkworm pupae meal (diet A) or $4 \%$ mealworm larvae meal (diet B). The experiment lasted for 55 days and growth performance as well chemical and amino acid meat composition and the profile of fatty acids were evaluated during the study. The results showed that dietary supplementation of insect meals caused increases in final body weight and carcass meat content in rabbits from the experimental groups. The experimental diets had no effect on the sum of essential amino acids in the studied muscles, but created differences in the level of some amino acids: phenylalanine, lysine, tryptophan, threonine, isoleucine and methionine. The concentration of saturated (SFA) and monounsaturated fatty acids (MUFA) in the muscles was comparable in all the groups. In the tissues of rabbits fed the silkworm meal diet, PUFA-3 concentration increased and cholesterol level decreased. It is concluded that dried silkworm pupae and mealworm larvae meals can be used as feed material in rabbit diets at $\mathbf{4 \%}$ inclusion level without any adverse effect on growth performance, as well as quality and dietetic value of rabbit meat.
\end{abstract}

Key words: rabbit, feeding, Bombyx mori, Tenebrio molitor, meat quality

Insect meals have a high nutritional value and their protein content ranges from 40 to $60 \%$ depending on development stage and species. Meals from insects of the order Diptera have a similar amino acid profile to fish meals, whereas the amino acid profile of insects of the order Coleoptera or Orthoptera is similar to soybean with

\footnotetext{
*Work financed from statutory activity: 01-14-01-11.
} 
a possible lysine or methionine deficiency (Barosso, 2014). The average content of nutritionally important fat in insect meals varies between $14.41 \%$ and $37.1 \%$, being higher for larvae and pupae than for adult forms. Insects are relatively rich in unsaturated acids, including oleic, linoleic and $\alpha$-linolenic acids (Yang, 2006).

Insects can be reared using organic byproducts, which reduces their contamination and converts them into high-protein feed. Insect breeding does not impact the environment more negatively than conventional livestock farms, shows a relatively low carbon dioxide emission into the atmosphere as well as lower greenhouse gas and ammonia emissions (Oonincx et al., 2010). Another benefit for the environment is the high food conversion efficiency of insects, which is associated with their poikilothermic physiology (Nijdam et al., 2012).

Because insects show great potential as a source of nutrients (protein) and active substances (polyunsaturated fatty acids, antimicrobial peptides), they can be used in the diet of various animal species. Most research studies on feeding farm animals with insect meals or oils were conducted with poultry (Józefiak et al., 2018). Birds raised with outdoor access eat insects at all stages of life, which shows they are evolutionarily adapted to this kind of diet; therefore, feeding insect-supplemented diets to indoor housed birds has a positive effect on their development (Allegretti et al., 2017). Recently, several experiments on the use of insects as feed material have been also conducted on dogs (Kierończyk et al., 2018 a, b; Lei et al., 2019) and pigs (Neumann et al., 2018; Spranghers et al., 2019). However, the results obtained with poultry or other species cannot be directly applied to rabbits due to considerable physiological differences between different animals species.

In the case of rabbits, only Carregal and Takahashi (1987) studied the possibility of replacing soybean meal with silkworm pupae in their diets. In the study by Liu et al. (1987), silkworm pupae were not treated as an experimental factor but were a regular component of the rabbit diet, which may be indicative of their widespread use in China. In recent years, Gasco et al. (2017), Dalle Zotte et al. (2018) and Martins et al. (2018) demonstrated the possibility of using oil from black soldier fly (Hermetia illucens) and mealworm (Tenebrio molitor) in rabbit diets. Therefore, the aim of the study was to evaluate the effect of feeding rabbits with diets containing dried silkworm pupae and mealworm larvae meals on their slaughter value and meat quality.

\section{Material and methods}

\section{Animals and diets}

The study material consisted of sixty New Zealand White rabbits, weaned at 35 days of age, from a farm belonging to the National Research Institute of Animal Production in Aleksandrowice. Three pelleted diets were made (Table 1) for the purposes of this study: a control diet (C) and two experimental diets: diet A with 4\% dried silkworm pupae meal (Bombyx mori) and diet B with 4\% dried mealworm larvae meal (Tenebrio molitor). The rabbits were divided into 3 groups (with 20 animals per group) and fed ad libitum one of the three diets. The experiment lasted 55 days until animals reached 90 days of age. 
Table 1. Composition of the diets ( $\%)$

\begin{tabular}{l|r|c|c}
\hline \multirow{2}{*}{\multicolumn{1}{c}{ Components }} & \multicolumn{3}{c}{ Diet } \\
\cline { 2 - 4 } & C & A & B \\
\hline Soybean meal & 10 & 5 & 5 \\
Silkworm pupae & 0 & 4 & 0 \\
Mealworm larvae & 0 & 0 & 4 \\
Lucerne meal & 25 & 25 & 25 \\
Rapeseed meal & 4 & 4 & 4 \\
Maize DDGS & 4 & 4 & 4 \\
Wheat bran & 25 & 26 & 26 \\
Ground wheat & 5 & 5 & 5 \\
Ground barley & 10 & 10 & 10 \\
Dried sugar beet pulp & 7 & 7 & 7 \\
Arbocel & 5 & 5 & 5 \\
Fodder yeast & 1 & 1 & 1 \\
Dried whey & 1 & 1 & 1 \\
Salt & 0.2 & 0.2 & 0.2 \\
Ground limestone & 1.3 & 1.3 & 1.3 \\
Feed phosphate & 0.5 & 0.5 & 0.5 \\
Vitamin-mineral preparation & 1 & 1 & 1 \\
Total & 100 & 100 & 100 \\
\hline
\end{tabular}

Table 2. Chemical composition of the diets and experimental factors (\% DM), and gross energy content $(\mathrm{MJ} / \mathrm{kg} \mathrm{DM})$

\begin{tabular}{|c|c|c|c|c|c|c|}
\hline \multirow{2}{*}{ Item } & \multicolumn{3}{|c|}{ Diet } & \multirow{2}{*}{$\begin{array}{c}\text { Extracted } \\
\text { soybean meal }\end{array}$} & \multirow{2}{*}{$\begin{array}{l}\text { Silkworm } \\
\text { pupae }\end{array}$} & \multirow{2}{*}{$\begin{array}{c}\text { Mealworm } \\
\text { larvae }\end{array}$} \\
\hline & $\mathrm{C}$ & A & B & & & \\
\hline Dry matter & 89.20 & 89.40 & 89.40 & 89.35 & 94.40 & 94.30 \\
\hline Crude ash & 7.93 & 7.83 & 7.80 & 6.73 & 4.40 & 3.40 \\
\hline Crude protein & 18.71 & 18.77 & 18.76 & 50.26 & 51.75 & 51.34 \\
\hline Crude fat & 3.12 & 4.01 & 4.14 & 2.15 & 24.19 & 27.95 \\
\hline NDF & 27.46 & 27.13 & 27.30 & 15.02 & 6.49 & 11.42 \\
\hline $\mathrm{ADF}$ & 15.41 & 15.30 & 15.38 & 7.84 & 5.49 & 7.59 \\
\hline $\mathrm{ADL}$ & 3.61 & 3.55 & 3.50 & 3.96 & 2.46 & 1.26 \\
\hline Lysine & 0.87 & 0.86 & 0.85 & 3.27 & 2.90 & 2.82 \\
\hline Methionine+cystine & 0.52 & 0.55 & 0.51 & 1.41 & 2.13 & 1.07 \\
\hline Threonine & 0.69 & 0.70 & 0.71 & 1.91 & 2.11 & 2.16 \\
\hline Tryptophan & 0.24 & 0.24 & 0.24 & 0.66 & 0.71 & 0.61 \\
\hline Gross energy & 16.86 & 17.14 & 17.02 & 16.38 & 23.94 & 22.50 \\
\hline
\end{tabular}


Table 3. Profile of selected fatty acids (\% of total fatty acids)

\begin{tabular}{l|r|r|r|r|r|r}
\hline Fatty acid & C & $\begin{array}{c}\text { Soybean } \\
\text { meal }\end{array}$ & A & $\begin{array}{c}\text { Silkworm } \\
\text { pupae }\end{array}$ & B & $\begin{array}{c}\text { Mealworm } \\
\text { larvae }\end{array}$ \\
\hline $\mathrm{c} 12: 0$ & 0.01 & 0.08 & 0.07 & 0.27 & 0.19 & 0.42 \\
$\mathrm{c} 14: 0$ & 0.21 & 0.00 & 0.23 & 0.18 & 0.95 & 2.47 \\
$\mathrm{c} 16: 0$ & 14.39 & 15.22 & 18.97 & 24.65 & 16.98 & 16.94 \\
$\mathrm{c} 18: 0$ & 2.11 & 4.49 & 3.95 & 6.12 & 2.59 & 2.72 \\
$\mathrm{c} 16-1 n-7$ & 0.34 & 0.06 & 0.80 & 0.86 & 1.01 & 1.68 \\
$\mathrm{c} 18-1 n-9$ & 20.92 & 13.69 & 30.46 & 29.98 & 31.59 & 31.55 \\
$\mathrm{c} 18-2 n-6$ & 48.20 & 55.12 & 26.68 & 6.97 & 34.34 & 40.22 \\
$\mathrm{c} 18-3 n-3$ & 13.05 & 8.72 & 17.37 & 33.12 & 10.84 & 3.36 \\
EPA & 0.02 & 0.05 & 0.05 & 0.04 & 0.05 & 0.07 \\
DHA & 0.44 & 0.08 & 0.36 & 0.11 & 0.34 & 0.14 \\
SFA & 16.84 & 21.87 & 24.03 & 31.62 & 21.51 & 22.79 \\
UFA & 83.16 & 78.13 & 75.97 & 68.38 & 78.49 & 77.21 \\
PUFA & 61.83 & 64.38 & 44.52 & 37.52 & 45.67 & 43.92 \\
PUFA-6 & 48.32 & 55.12 & 27.09 & 7.25 & 34.79 & 40.35 \\
PUFA-3 & 13.51 & 8.86 & 17.42 & 33.27 & 10.89 & 3.57 \\
PUFA 6/3 & 3.58 & 6.22 & 1.56 & 0.21 & 3.20 & 11.29 \\
\hline
\end{tabular}

All the feed and muscle tissue analyses were performed at the accredited Central Laboratory of the National Research Institute of Animal Production in Aleksandrowice. The ingredients (extracted soybean meal, insect meals) and the mixed diets were subjected to basic analyses, and the content of selected amino acids and fatty acids was determined (Tables 2 and 3). Moisture content, crude ash, crude protein and crude fat were determined based on the Commission Regulation (EC) No $152 / 2009$ laying down the methods of sampling and analysis for the official control of feed - accredited methods. Crude fibre, NDF, ADF and ADL were determined according to SOP M.003 ver. 1 of 17 September 2001 - non-accredited methods (Table 2).

\section{Productive performance and slaughter}

In order to evaluate the production results, individual body weight of the rabbits was determined at 35 and 90 days of age. At the end of the experimental rearing period (90 days of age) animals were subjected to 24 hours of feed withdrawal and slaughtered in an on-site abattoir in accordance with the procedures provided for this group of animals (Council Regulation (EC) No 1099/2009). Ten rabbits from each group were slaughtered and dissected to determine hot carcass weight, carcass muscle content, and carcass content of inguinal, perirenal and shoulder fat.

\section{Meat composition}

The analysis of meat quality included the determination of basic chemical composition, amino acids, and the profile of higher fatty acids. The chemical traits of rabbit meat were determined in 50-g meat samples from hind leg ( $m$. biceps femoris) and saddle ( $m$. longissimus lumborum). The meat was trimmed of membranes and 
tendons, and ground once in a Moulinex mill. The free fat content was determined by Soxhlet according to PN-ISO 1444:2000, protein content by Kjeldahl according to PN-75/A-04018, water content according to PN-ISO 1442:2000, and total ash content according to PN-ISO 936:2000 (Meat and meat products).

The amino acids and fatty acids in meat samples were determined using the methods described above for feed analysis, and total cholesterol using the GC method in meat and dried milk (SOP M.023a of 2011).

The atherogenic (AI) and thrombogenic indexes (TI) were calculated based on the formulae given by Ulbricht and Southgate (1991), where:

1.

$$
\begin{gathered}
A I=\frac{C_{12: 0}+4 C_{14: 0}+C_{16: 0}}{P U F A_{n-3}+P U F A_{n-6}+M U F A} \\
I T=\frac{C_{14: 0}+C_{16: 0}+C_{18: 0}}{0,5 M U F A+0,5 P U F A_{n-6}+3 P U F A_{n-3}+\frac{P U F A_{n-3}}{P U F A_{n-6}}}
\end{gathered}
$$

Selected amino acids in acid hydrolysates of feeds and the biological material were determined according to SOP M.004 ver. 7 of 16 March 2012; cystine and methionine according to SOP M.005 ver. 7 of 16 March 2012, and tryptophan according to SOP M.006 of 21 February 2008 (Table 2). Fatty acids were determined by extraction in chloroform and methanol solution according to Folch et al. (1957). Fatty acid methyl esters were prepared according to ISO 12966-2:2011. The fatty acid profile of relevant methyl esters was determined by gas chromatography using a VARIAN 3400 gas chromatograph with a flame ionization detector (FID), injector temperature $250^{\circ} \mathrm{C}$, and column Rtx $2330(105 \mathrm{~m} \times 0.32 \mathrm{~mm} \times 0.2 \mu)$. The flow rate of the carrier gas (helium) was $3 \mathrm{ml} / \mathrm{min}$, injection volume was $0.7 \mathrm{mcl}$. CLA was determined using acid standards obtained from Larodan Fine Chemicals AB, and the other acids using Sigma-Aldrich standards (Table 3).

\section{Statistical analyses}

Data were analysed by one-way analysis of variance (ANOVA). Significant differences between the means in groups were estimated by Duncan's multiple range test at a $\mathrm{P} \leq 0.05$ level of significance. The calculations were made using Statistica 13.1 PL.

\section{Results}

It is evident from the present results that the initial body weights were uniform (773.3-782.5 g), but at 90 days of age significant $(\mathrm{P} \leq 0.05)$ differences were observed between group $\mathrm{C}$ and both experimental groups (Table 4). The animals from experimental groups were heavier by $202.1 \mathrm{~g}$ (A) and $180.8 \mathrm{~g}$ (B) compared to those 
from group C. Hot carcass weight with head did not differ significantly between the groups, although there was an upward trend analogous to live weight. Carcass muscle weight was highest in group $\mathrm{A}$ and the differences between groups $\mathrm{A}$ and $\mathrm{C}$ were significant at $\mathrm{P} \leq 0.05$. No statistically significant differences between the groups were found for the amounts of inguinal, shoulder and perirenal fat.

Table 4. Production and slaughter results ( $g$; mean \pm SEM)

\begin{tabular}{l|c|c|c|c}
\hline \multirow{2}{*}{ Item } & \multicolumn{3}{c|}{ Group } & \multirow{2}{*}{ P-value } \\
\cline { 2 - 4 } & $\mathrm{C}$ & $\mathrm{A}$ & $\mathrm{B}$ & \\
\hline Body weight at 35 days of age & $778.30 \pm 9.60$ & $782.50 \pm 6.64$ & $773.30 \pm 7.21$ & 0.717 \\
Body weight at 90 days of age & $2404.00 \pm 27.21 \mathrm{~b}$ & $2606.50 \pm 23.10 \mathrm{a}$ & $2584.80 \pm 21.48 \mathrm{a}$ & $<0.001$ \\
Hot carcass weight with head & $1270.80 \pm 17.10$ & $1437.70 \pm 22.60$ & $1356.00 \pm 17.30$ & $<0.001$ \\
Weight of carcass muscles & $914.90 \pm 17.10 \mathrm{~b}$ & $1092.50 \pm 45.20 \mathrm{a}$ & $1056.70 \pm 14.52$ & 0.001 \\
Weight of inguinal fat & $4.66 \pm 0.84$ & $4.33 \pm 0.49$ & $4.83 \pm 0.40$ & 0.841 \\
Weight of shoulder fat & $12.50 \pm 1.78$ & $9.67 \pm 0.61$ & $12.33 \pm 0.92$ & 0.212 \\
Weight of perirenal fat & $14.16 \pm 1.53$ & $17.66 \pm 2.78$ & $15.83 \pm 1.53$ & 0.088 \\
\hline
\end{tabular}

$\mathrm{a}, \mathrm{b}-$ values in rows with different letters differ significantly $(\mathrm{P} \leq 0.05)$.

Basic analysis of the meat (dry matter, total ash, crude protein, crude fat) did not show significant differences in hind leg muscles and saddle muscles between the rabbit groups under study (Table 5). Non-significantly highest protein content was determined in saddle muscles from group A (23.37\%), and lowest in hind leg muscles from group C (21.85\%). A similar trend occurred for saddle muscles. Fat was higher in the leg muscles of rabbits from groups A and B, which received insect meal diets. The opposite situation existed for saddle muscles, the samples of which contained more fat in the case of rabbits from group $\mathrm{C}$.

Table 5 . Basic analysis of meat $(\%$; mean \pm SEM)

\begin{tabular}{l|c|c|c|c|c|c|c|c}
\hline \multirow{2}{*}{ Item } & \multicolumn{4}{|c|}{ Hind leg muscles/Group } & \multicolumn{4}{c}{ Saddle muscles/Group } \\
\cline { 2 - 9 } & $\mathrm{C}$ & $\mathrm{A}$ & $\mathrm{B}$ & P-value & $\mathrm{C}$ & $\mathrm{A}$ & $\mathrm{B}$ & P-value \\
\hline Dry matter & $23.84 \pm 0.17$ & $24.51 \pm 0.27$ & $24.42 \pm 0.30$ & 0.161 & $25.28 \pm 0.26$ & $24.90 \pm 0.16$ & $24.87 \pm 0.17$ & 0.304 \\
Crude ash & $1.19 \pm 0.00$ & $1.190 \pm 0.01$ & $1.21 \pm 0.01$ & 0.192 & $1.23 \pm 0.02$ & $1.22 \pm 0.01$ & $1.25 \pm 0.01$ & 0.525 \\
Crude & $21.85 \pm 0.15$ & $22.10 \pm 0.17$ & $21.88 \pm 0.10$ & 0.442 & $22.98 \pm 0.20$ & $23.37 \pm 0.16$ & $22.95 \pm 0.20$ & 0.246 \\
protein & & & & & & & & \\
Crude fat & $1.72 \pm 0.11$ & $2.06 \pm 0.20$ & $2.25 \pm 0.30$ & 0.261 & $1.90 \pm 0.37$ & $1.22 \pm 0.05$ & $1.38 \pm 0.09$ & 0.113 \\
\hline
\end{tabular}

No statistically significant differences.

The sum of essential amino acids in hind leg muscles did not differ significantly between the groups (Table 6). Statistically significant $(\mathrm{P} \leq 0.05)$ differences were 
noted for phenylalanine between group $\mathrm{C}$ and groups $\mathrm{A}$ and $\mathrm{B}$. In addition, more phenylalanine was found in the muscles of rabbits fed the silkworm meal compared to mealworm meal diet. Lysine was more abundant in the samples from $\mathrm{C}$ compared to $\mathrm{A}$ and $\mathrm{B}$ rabbits. In the case of tryptophan, differences were observed between group $\mathrm{A}$ and groups $\mathrm{C}$ and $\mathrm{B}$.

Table 6. Amino acids content of hind leg muscles (g/100 g protein; mean $\pm \mathrm{SEM})$

\begin{tabular}{|c|c|c|c|c|}
\hline \multirow{2}{*}{ Amino acids } & \multicolumn{3}{|c|}{ Group } & \multirow{2}{*}{ P-value } \\
\hline & $\mathrm{C}$ & A & $\mathrm{B}$ & \\
\hline Thr & $4.64 \pm 0.07$ & $4.47 \pm 0.10$ & $4.64 \pm 0.10$ & 0.304 \\
\hline Val & $5.15 \pm 0.11$ & $5.02 \pm 0.13$ & $5.15 \pm 0.10$ & 0.663 \\
\hline Ile & $3.98 \pm 0.09$ & $3.85 \pm 0.07$ & $3.97 \pm 0.09$ & 0.470 \\
\hline Leu & $7.61 \pm 0.19$ & $7.63 \pm 0.15$ & $7.88 \pm 0.14$ & 0.425 \\
\hline Phe & $4.96 \pm 0.12 \mathrm{a}$ & $4.63 \pm 0.13 \mathrm{ab}$ & $4.35 \pm 0.09 \mathrm{~b}$ & 0.007 \\
\hline Lys & $10.68 \pm 0.24 \mathrm{a}$ & $9.61 \pm 0.31 \mathrm{~b}$ & $8.94 \pm 0.19 b$ & $<0.001$ \\
\hline Met & $2.49 \pm 0.05$ & $2.38 \pm 0.03$ & $2.49 \pm 0.13$ & 0.539 \\
\hline Trp & $1.26 \pm 0.12 b$ & $1.61 \pm 0.09 \mathrm{a}$ & $1.31 \pm 0.03 \mathrm{~b}$ & 0.031 \\
\hline Sum of essential amino acids & $36.13 \pm 0.64$ & $34.73 \pm 0.76$ & $34.09 \pm 0.51$ & 0.109 \\
\hline
\end{tabular}

$\mathrm{a}, \mathrm{b}-$ values in rows with different letters differ significantly $(\mathrm{P} \leq 0.05)$.

Likewise, the sum of essential amino acids in saddle muscles showed no significant differences between the groups (Table 7). There was more threonine and methionine in the muscle samples of animals from group B compared to those from groups $\mathrm{A}$ and $\mathrm{C}$. Isoleucine was more abundant in groups $\mathrm{A}$ and $\mathrm{B}$ compared to group $\mathrm{C}$, and tryptophan was higher in group $\mathrm{C}$ than in the other groups.

Table 7. Amino acids content of saddle muscles (g/100 g protein; mean \pm SEM)

\begin{tabular}{|c|c|c|c|c|}
\hline \multirow{2}{*}{ Amino acids } & \multicolumn{3}{|c|}{ Group } & \multirow{2}{*}{ P-value } \\
\hline & $\mathrm{C}$ & A & B & \\
\hline Thr & $4.23 \pm 0.09 \mathrm{~b}$ & $4.14 \pm 0.14 b$ & $4.68 \pm 0.11 \mathrm{a}$ & 0.009 \\
\hline Val & $4.59 \pm 0.12$ & $4.56 \pm 0.14$ & $4.29 \pm 0.07$ & 0.177 \\
\hline Ile & $3.77 \pm 0.07 \mathrm{~b}$ & $4.23 \pm 0.07 \mathrm{a}$ & $4.21 \pm 0.06 \mathrm{a}$ & $<0.001$ \\
\hline Leu & $7.41 \pm 0.14$ & $7.62 \pm 0.16$ & $7.42 \pm 0.09$ & 0.491 \\
\hline Phe & $3.59 \pm 0.06$ & $3.74 \pm 0.06$ & $3.69 \pm 0.05$ & 0.197 \\
\hline Lys & $8.09 \pm 0.20$ & $8.37 \pm 0.28$ & $7.90 \pm 0.14$ & 0.317 \\
\hline Met & $2.08 \pm 0.04 \mathrm{~b}$ & $2.14 \pm 0.03 \mathrm{~b}$ & $2.70 \pm 0.08 \mathrm{a}$ & $<0.001$ \\
\hline $\operatorname{Trp}$ & $2.88 \pm 0.11 \mathrm{a}$ & $2.89 \pm 0.11 \mathrm{a}$ & $2.33 \pm 0.12 \mathrm{~b}$ & 0.004 \\
\hline Sum of essential amino acids & $32.41 \pm 0.56$ & $33.55 \pm 0.66$ & $32.54 \pm 0.43$ & 0.206 \\
\hline
\end{tabular}

$\mathrm{a}, \mathrm{b}$ - values in rows with different letters differ significantly $(\mathrm{P} \leq 0.05)$. 


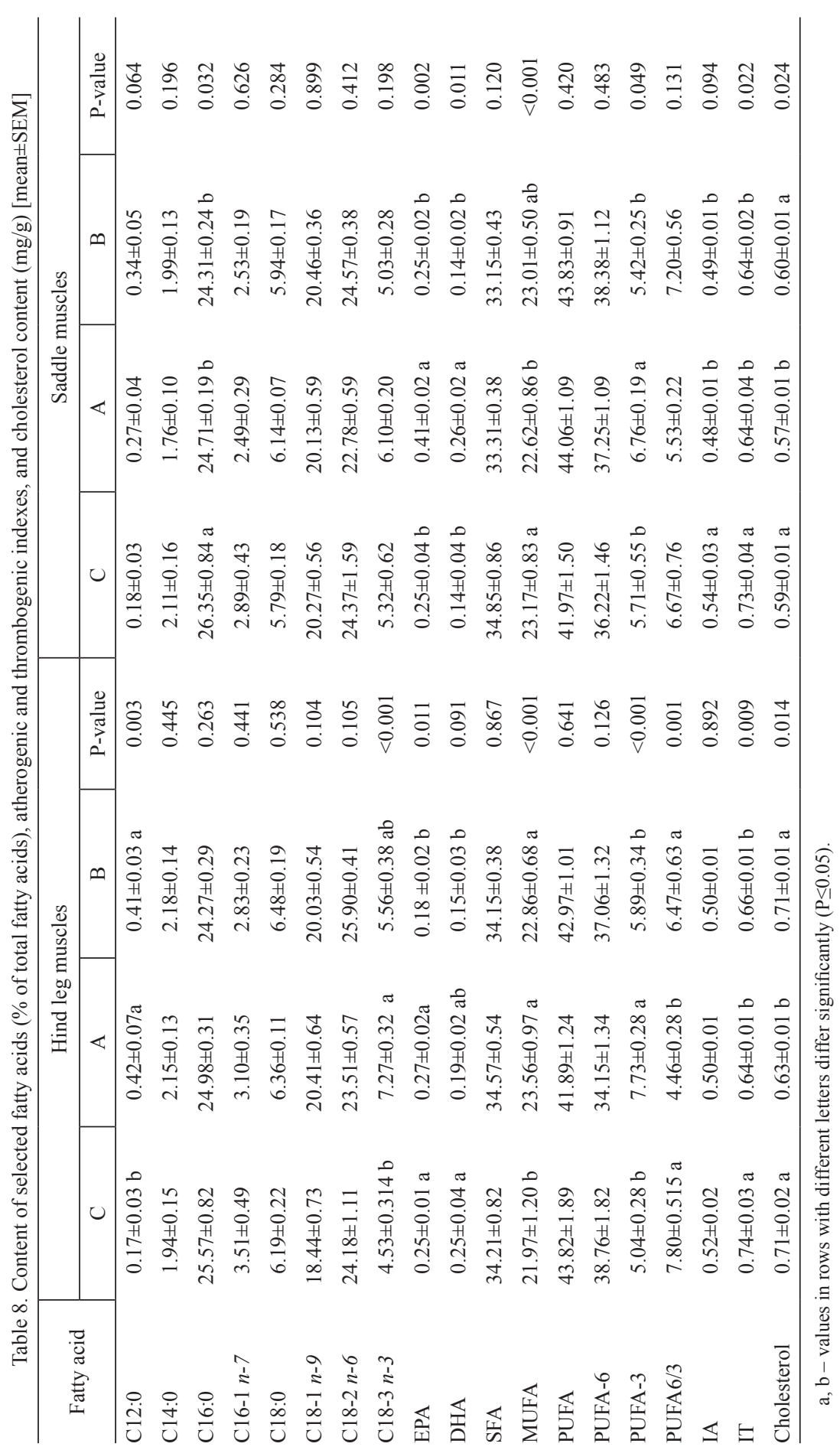


The dietary supplementation of the two insect meals modified the profile of fatty acids (Table 8 ) by increasing the level of lauric acid (C:12:0) in hind leg muscles $(\mathrm{p} \leq 0.05)$ and by reducing the level of palmitic acid $(\mathrm{C} 16: 0)$ in saddle muscles $(\mathrm{P} \leq 0.05)$. For hind leg muscles, differences $(\mathrm{P} \leq 0.05)$ were observed for the concentration of linolenic acid (C18:3n-3) between group $\mathrm{A}$ and groups $\mathrm{C}$ and $\mathrm{B}$. In the saddle muscles, this difference was not significant, but the level of this acid showed an upward trend in group A. The increase in its concentration caused statistically significant $(\mathrm{P} \leq 0.05)$ differences in the content of $n-3$ PUFA between group A and the other groups for both hind leg and saddle muscles. The hind leg muscles of rabbits from group $\mathrm{B}$ had significantly $(\mathrm{P} \leq 0.05)$ the lowest EPA content in relation to the other groups, whereas in saddle muscles EPA was highest in group $\mathrm{A}(\mathrm{P} \leq 0.05)$. In the control group, the hind leg muscles contained the highest amounts of $\mathrm{DHA}(\mathrm{P} \leq 0.05)$, and in saddle muscles this amount was highest in group A with significant $(\mathrm{P} \leq 0.05)$ differences in relation to the other groups.

The concentration of MUFA in the hind leg muscles was significantly $(\mathrm{P} \leq 0.05)$ higher in groups A and B than in group C. In the saddle muscles, least MUFA were noted in group $\mathrm{A}$. The difference between groups $\mathrm{A}$ and $\mathrm{C}$ was significant at $\mathrm{P} \leq 0.05$.

Nutritionally the most desirable $n-6 / n-3$ PUFA ratio of 4.462 was observed in group $\mathrm{A}$ in the hind leg muscles. This difference proved statistically significant $(\mathrm{P} \leq 0.05)$ in relation to the other groups. Likewise, non-significantly the lowest $n-6 / n-3$ PUFA ratio of 5.527 was noted in saddle muscles from group A.

There were significant $(\mathrm{P} \leq 0.05)$ decreases in the thrombogenic index for saddle and hind leg muscles, and in the atherogenic index for saddle muscles when rabbits were fed diets with $4 \%$ silkworm pupae meal and 4\% mealworm larvae meal.

In the experimental group receiving silkworm pupae meal, the level of cholesterol was significantly $(\mathrm{P} \leq 0.05)$ lower in both saddle and hind leg muscles when compared to the other groups.

\section{Discussion}

The results obtained should be considered in the context of diet composition. The study diets were comparable in terms of crude protein content, but it was slightly higher in the experimental groups as a result of the higher crude protein content of insect meals compared to soybean meal. No differences were found in the content of nutritionally important NDF, ADF and ADL fractions (Table 2). Dietary supplementation of the $4 \%$ insect meal modified the fatty acid profile of the diets (Table 3). Total SFA was highest in diets A and B, and the oleic acid content (C18:1 n-9) followed a similar pattern, while linoleic acid (C18:2 n- 6$)$ and PUFA were dominant in the fatty acid profile of diet C.

Our study revealed statistically significant differences in the final body weight in favour of the experimental groups. There are no reports in the literature relating to the effect of the dietary supplementation of insects on growth of rabbits. The obtained differences could be linked to the slightly higher energy value of the experi- 
mental diets, resulting from the presence of insect meals. According to Finke (2013), insects are a rich source of easily assimilable fat. Gasco et al. (2019), who replaced $1.5 \%$ soybean oil supplement with 50 or $100 \%$ fat from mealworm larvae or black soldier fly larvae, observed slightly (non-significantly) higher body weights of rabbits in the experimental groups. The same study found no negative effect of insect oil on rabbit health. In pigs supplemented with Hermetia illucens larvae, Spranghers et al. (2017) observed the antimicrobial activity of C12:0 acid, which may represent an important added value and reduce the use of antibiotics in livestock breeding. Meals and oils from most insect larvae are a rich source of C12:0 fatty acid. This was also established in the present study for mealworm larvae (Table 3). Thus, the health-promoting effect of insect products may indirectly be a factor increasing the productivity of animals, e.g. by increasing body weights. However, this issue requires further study. In general, the body weights obtained in all the groups fall within the limits for growing rabbits of medium breeds under European conditions (Chełmińska and Kowalska, 2013; Strychalski et al., 2014). In turn, the higher muscle weight in the carcasses of experimental animals resulted from the higher carcass weights in these groups and from the weight of fat which showed no significant differences. The fat content of rabbits in the experimental groups was found to be relatively low. Kowalska et al. (2014), who studied the relationship between fatness of different carcass parts and intramuscular fat content, observed that New Zealand White rabbits fed a complete pelleted diet and slaughtered at 90 days of age, contained $5.50 \mathrm{~g}$ of inguinal fat, $16.0 \mathrm{~g}$ of shoulder fat, $32.0 \mathrm{~g}$ of perirenal fat, and $1.52 \%$ of intramuscular fat. Therefore, reducing carcass fatness while maintaining the level of intramusuclar fat above $1 \%$, which was obtained in the present study, is optimal for the consumer as it has no adverse effects on the taste of rabbit meat.

The chemical composition of the hind leg and saddle muscles (Table 5) is typical of young meat rabbits. Pla et al. (2004) reported the protein content of different rabbit meat parts to range from 18.69 to $22.10 \%$, with the highest value found in saddle muscle. The level of protein in the longissimus dorsi muscle of New Zealand White rabbits ranged from 22.18 to $22.78 \%$ in the study by Daszkiewicz et al. (2012), and from 20.7 to $22.0 \%$ in the experiment of Chełmińska and Kowalska (2013). Maj et al. (2008), Daszkiewicz et al. (2012) and Chełmińska and Kowalska (2013) observed similar dry matter and ash levels in rabbit muscles. One of the main determinants of the sensory meat quality is intramuscular fat. Our results are consistent with those of other authors. The intramuscular fat content ranged from 2.11 to $2.31 \%$ in hind leg muscles (Kowalska and Bielański, 2011; Chełmińska and Kowalska, 2013), and from 1.01 to $1.52 \%$ in saddle muscles (Kowalska et al., 2014). Of note is the increase in the fat content of hind leg muscles in the experimental rabbits. This is hard to explain but can be cautiously linked to the observation of Gasco et al. (2017) that replacing soybean oil in rabbit diets with insect fat increases perirenal fat content in the carcasses. This interpretation cannot be fully accepted because no such relationships were noted for the saddle muscles. The fat and protein levels that we observed in saddle and hind leg meat correspond with the findings of other authors, which may indicate that the supplemented insect meals had no adverse effect on the basic chemical composition of rabbit meat. 
The quality, and thus the nutritive value, of protein depends on amino acid composition and digestibility of the protein fraction. Among the nine essential amino acids, lysine and threonine are strictly indispensable since they are not transaminated and their deamination is irreversible. In contrast, the seven other essential amino acids can participate in transamination reactions. In our study, we did not find any differences in the essential amino acids content of the saddle and hind leg muscles, which suggests that the 4\% supplement of insect meals did not adversely affect the essential amino acids content of rabbit meat (Tables 6 and 7). This fact probably results from the similar amino acids content of diet $\mathrm{C}$ and experimental diets (Table 3). It should be recalled that according to Barosso (2014), the amino acids composition of beetles (Coleoptera), including the mealworm, is similar to that of soybean. The levels of most amino acids that we determined in rabbit muscles were similar to those reported by Nasr et al. (2017) for different rabbit breeds and their crosses.

Numerous studies with rabbits have demonstrated that the quality of rabbit meat can be modified by dietary means. For example, it was found that PUFA tissue levels can be influenced by their dietary concentration (Parveen et al., 2016). Fatty acids in tissues may also originate from de novo synthesis or bioconversion of C18:3n-3 and C18:2 n-6 into appropriate long-chain PUFA (Masek et al., 2014).

In our study, the supplementation of soybean meal with two insect meals did not increase the amount of SFA in the analysed muscles, but the amount of PUFA3 significantly increased in the group supplemented with silkworm pupae meal. In both experimental groups, the thrombogenic index was significantly reduced in both saddle and hind leg muscles. The supplemental silkworm pupae and mealworm larvae meals significantly decreased the atherogenic index in saddle muscles, and nonsignificantly in hind leg muscles. These findings suggest that incorporation of these insect meals in rabbit diets has improved the composition of fatty acids in saddle and hind leg tissues, which considerably reduces the risk of cancer and atherosclerosis in consumers of this type of meat. Similar results were obtained by Kierończyk et al. (2018 b), who replaced soybean oil with mealworm larvae and superworm larvae meals in poultry diets. The application of these oils had a considerable effect on the composition of fatty acids in liver and breast tissues. But only the mealworm oil supplement had a positive effect on the concentration of SFA, MUFA, PUFA and UFA in breast muscle and on reducing the IA and IT indexes.

Sosa and Fogliano (2017) compared animal fats such as butter, lard and beef tallow with insect oils (superworm, mealworm, lesser mealworm, cricket, cockroach) and vegetable oils (linseed, rapeseed, sesame, sunflower, pumpkin, soybean). The authors concluded that in terms of their fatty acid profile, which shows a higher content of SFA (mainly C16:0 and C18:0), insect oils occupy a place in between vegetable oils and fats of animal origin. These findings are supported by the results presented in Table 3.

Research shows that diets rich in $n-3$ PUFA considerably reduce the level of triglycerides and cholesterol esters in the liver as well as the concentration of apoliprotein B (apoB) which contain LDL receptor lipoproteins (Vasandani et al., 2002). Therefore, the rabbit diet supplemented with $n$-3 PUFA-rich silkworm pupae caused a significant reduction in cholesterol level in both the saddle and hind leg muscles. 
Gessner et al. (2019), who fed mealworm larvae meal to obese rats, reported the amount of cholesterol to decrease significantly in both the liver and plasma of the rats.

\section{Conclusions}

It is concluded from the present study that dried silkworm pupae and mealworm larvae meals can be used as feed material in rabbit diets at $4 \%$ inclusion level without any adverse effect on growth performance, as well as quality, chemical composition and dietetic value of rabbit meat.

\section{References}

Allegretti G., Schmidt V., B ogorni P., Tala mini E., Ortega E. (2017). Insect as feed: An emergy assessment of insect meal as a sustainable protein source for the Brazilian poultry industry. J. Cleaner Prod., 171: 403-412.

Barroso F.G., De Haro C., S anchez-Muros M.J., Venegas E., Martinez-San$\mathrm{chez}$ A., P e re z b a N.C. (2014). The potential of various insect species for use as food for fish. Aquaculture, 422-423: 193-201.

Carregal R.D., Takahashi R. (1987). Use of silkworm (Bombyx mori L.) chrysalis meal as a replacement for soyabean meal in the feeding of growing rabbits. Rev. Soc. Bras. Zoot., 16: $158-162$.

Chełmińska A., Kowalska D. (2013). The effectiveness of maize DDGS in rabbit diets. Ann. Anim. Sci., 13: 571-585.

Dalle Zotte A., Cullere M., Martins C., Alves S.P., Freire J.P.B., Falcão-e-Cunh a L., B e s s a R.J.B. (2018). Incorporation of Black Soldier Fly (Hermetia illucens L.) larvae fat or extruded linseed in diets of growing rabbits and their effects on meat quality traits including detailed fatty acid composition. Meat Sci., 146: 50-58.

Daszkiewicz T., Gug ołek A., Janiszewsk i P., Kubiak D., C zoik M. (2012). The effect of intensive and extensive production systems on carcass quality in New Zealand White rabbits. World Rabbit Sci., 20: 25-32.

F inke M.D. (2013). Complete nutrient content of four species of feeder insect. Zoo Biol., 32: $27-36$.

F o l ch J., Le e s M., S tan ley G.H.S. (1957). A simple method for the isolation and purification of total lipids from animal tissues. J. Biol. Chem., 226: $497 \mathrm{pp}$.

Gasco L., Dabbou S., Meneguz M., Renna M., Brugiapaglia A., Dama A., Bressan E., Schiavone A., Trocino A., Gratta F., Birolo M., Xiccato G., Zoccarato I., G a i F. (2017). Partial or total substitution of soybean oil by Tenebrio molitor or Hermetia illucens fat in rabbit diets. Preliminary results: effects on growth and slaughtering performances. Book of abstracts of the INSECTA Conference 2017, Berlin, Germany, 7-8.09.2017, pp. 60-62.

Gasco L., Dabbou S., Trocino A., Xiccato G., Capucchio M.T., Biasato I., Dezzutto D., Birolo M., Meneguz M., Schiavone A., Gai F. (2019). Effect of dietary supplementation with insect fats on growth performance, digestive efficiency and health of rabbits. J. Anim. Sci. Biotechnol., 10: 2-9.

Gessner D.K., S chwarz A.S., We n G., Mos t E., Zorn H., Ringse is R., Eder K. (2019). Insect meal as alternative protein source exerts pronounced lipid-lowering effects in hyperlipidemic obese Zucker rats. J. Nutr., 149: 566-577.

Józefiak A., Ki erończyk B., Rawski M., Mazurkiewicz J., Benzertiha A., Gobbi P., Nogales-Mérida S., Świątkiewicz S., Józefiak D. (2018). Full-fat insect meals as feed additive - the effect on broiler chicken growth performance and gastrointestinal tract microbiota. J. Anim. Feed Sci., 27: 131-139.

Ki er ończy k B.,R a w s k i M.,P a w ełc zy k P.,Różyńs k a J.,Golus i k J.,Mi kołaj c zak Z., 
Jó ze fi a k D. (2018 a). Do insects smell attractive to dogs? A comparison of dog reactions to insects and commercial feed aromas - a preliminary study. Ann. Anim. Sci., 18: 795-800.

Ki erończyk B., Rawski M., Józefiak A., Mazurkiewicz J., Św iątkiewicz S., S i we k M., B ednarczyk M., Szuma cher-Strabel M., Ciéślak A., B enzertiha A., Jó z e fi a k D. (2018 b). Effects of replacing soybean oil with selected insect fats on broilers. Anim. Feed Sci. Tech., 240: 170-183.

Kowalska D., B i elańs ki P. (2011). Study on the possibility of using the native Popielno White rabbit breed in commercial farming. Ann. Anim. Sci., 11: 307-320.

Kow a ls k a D., G u g ołe k A., B i e lańs ki P. (2014). Relationships among fat deposit within carcass, content of intramuscular fat, fatty acid profile, and tenderness of rabbit meat (in Polish). Zywn. Nauk. Technol. Ja., 2: 58-72.

L e i X.J., K i m T.H., P a r k J.H., K i m I.H. (2019). Evaluation of supplementation of defatted black soldier fly (Hermetia illucens) larvae meal in beagle dogs. Ann. Anim. Sci., 19: 767-777.

L i u M.L., Ta n g L.M., Ya n J.P., L i u Y.G. (1987). Effects of concentrated rapeseed protein on growing rabbits. J. Sichuan Agricult. Univ., 2: 20-22.

Maj D., B i e ni e k J., Ła p a P. (2008). Meat quality of New Zealand White and Californian rabbits and their crosses (in Polish). Med. Weter., 64: 351-353.

Martins C., Cullere M., Dalle Zotte A., Cardosi C., Alves S.P., B ess a R.J.B., Freire J.P.B., F a l c ã o-e-Cunha L. (2018). Incorporation of two levels of black soldier fly (Hermetia illucens L.) larvae fat or extruded linseed in diets of growing rabbits: effects on growth performance and diet digestibility. Czech J. Anim. Sci., 63: 356-362.

Masek T., Starcevic K., Filipovic N., Stojevic Z., Brozic D., Gottstein Z., Severin K. (2014). Tissue fatty acid composition and estimated D desaturase activity after castration in chicken broilers fed with linseed or sunflower oil. Anim. Physiol. Anim. Nutr., 98: 384-392.

$\mathrm{N}$ a s r M.A., A b d - E $1 \mathrm{~h}$ a m i d T., H u s s e in M.M. (2017). Growth performance, carcass characteristics, meat quality and muscle amino-acid profile of different rabbits breeds and their crosses. Meat Sci., 134: 150-157.

N e u mann C., Velt en S., Li ebert F. (2018). N balance studies emphasize the superior protein quality of pig diets at high inclusion level of algae meal (Spirulina platensis) or insect meal (Hermetia illucens) when adequate amino acid supplementation is ensured. Animals, 8: 172.

Nij d a m D., R o od T., We s th o e k H. (2012). The price of protein: review of land use and carbon footprints from life cycle assessments of animal food products and their substitutes. Food Policy, 37: 760-770.

O on incx D.G.A.B., Van It terbeeck J., Heetkamp M.J.W., Van Den Brand H., Van L o o n J.J.A., Van Hu is A. (2010). An exploration on greenhouse gas and ammonia production by insect species suitable for animal or human consumption. Plos One, 5: 12.

Parveen R., Khan M.I., Anjum F.M., Sheikh M.A. (2016). Investigating potential roles of extruded flaxseed and a-tocopherol acetate supplementation for production of healthier broiler meat. Br. Poult. Sci., 57: 566-575.

P la M., P a s c u a l M., A ri n o B. (2004). Protein, fat and moisture content of retail cuts of rabbit meat evaluated with the NIRS methodology. World Rabbit Sci., 2: 149-158.

Schiavone A., Cullere M., De Marco M., Meneguz M., Biasato I., Bergagna S., Dezzutto D., Gai F., Dabbou S., Gasco L., Dalle Zotte A. (2017). Partial or total replacement of soybean oil by black soldier larvae (Hermetia illucens L.) fat in broiler diets: effect on growth performances, feed-choice, blood traits, carcass characteristics and meat quality. Ital. J. Anim. Sci., 16: 93-100.

Schiavone A., Dabbou S., De Marco M., Cullere M., Biasato I., Biasibetti E., Capucchio M.T., Bergagna S., Dezzutto D., Meneguz M., Gai F., Dalle Zotte A., G a s c o L. (2018). Black soldier fly (Hermetia illucens L.) larva fat inclusion in finisher broiler chicken diet as an alternative fat source. Animal, 12: 2032-2039.

S mith R., Prior R. (2013). Insects as sustainable sources of protein. Proteinsect. Work Package5: Pro-Insect Platform in Europe. Minerva Derivelable 5.1 - Mapping Expertise Report with regard to current Legislation\& Regulation: Europe and Africa\&China.

S o s a D.A.T., F o g li a n o V. (2017). Potential of insect-derived ingredients for food applications. In: Insect Physiology and Ecology, Shields V.D.C. (ed.). InTechOpen, Rijeka, Croatia, pp. 215-231. 
Spranghers T., Ottoboni M., Klootwijk C., Ovyn A., Deboosere S., De Meulenaer B., Michiels J., Eeckhout M., De Clercq P., De Smet S. (2017). Nutritional composition of black soldier fly (Hermetia illucens) prepupae reared on different organic waste substrates. J. Sci. Food Agr., 97: 2594-2600.

Spranghers T., Michiels J., Vrancx J., Ovyn A., Eeckhout M., De Clercq P., De $\mathrm{S}$ m e t S. (2018). Gut antimicrobial effects and nutritional value of black soldier fly (Hermetia illucens L.) prepupae for weaned piglets. Anim. Feed Sci. Technol., 235: 33-42.

Strychalski J., Juskiewicz J., Gugolek A., Wyczling P., Daszkiewicz T., Zwoli n s k i C. (2014). Usability of rapeseed cake and wheat-dried distillers' grains with solubles in the feeding of growing Californian rabbits. Arch. Anim. Nutr., 68: 227-244.

S zk u cik K., Libelt K. (2006). Nutritional value of rabbit meat (in Polish). Med. Weter., 62: 108110.

U 1 bri cht T.L.V., S o u th g a te D.A.T., (1991). Coronary heart disease: seven dietary factors. Lancet, 338: 985-992.

Vas andi C., Kafrouni A.I., Caronna A., B a shmakov Y., Gotthard M., Horton J.D., $\mathrm{S} p$ a d y D.K. (2002). Upregulation of hepatic LDL transport by $n-3$ fatty acids in LDL receptor knock out mice. J. Lipid Res., 43: 772-784.

Yang L.F., S i r i a m or n p u n S., Li D. (2006). Polyunsaturated fatty acid content of edible insects in Thailand. J. Food Lipids, 13: 277-285.

http://dx.doi.org/10.1016/0140-6736(91)91846-MISO 12966-2:2011. Animal and vegetable fats and oils. Gas chromatography of fatty acid methyl esters - Part 2: Preparation of methyl esters of fatty acids.

https://eur-lex.europa.eu/legal-content/EN/TXT/?uri=CELEX\%3A32017R0893

PN-75/A-04018. Agri-food products. Determination of nitrogen according to Kjeldahl and conversion to protein.

PN-ISO 1444:2000. Meat and meat products. Determination of free fat content.

Received: 9 IX 2019

Accepted: 5 XI 2019 